\title{
The Effects of Foreign Direct Investment and Economic Absorptive Capabilities on the Economic Growth of the Lao People's Democratic Republic
}

\author{
Phouthakannha NANTHARATH ${ }^{1}$, Eungoo KANG ${ }^{2}$ \\ Received: June 17, 2019 Revised: June 23, 2019 Accepted: July 3, 2019
}

\begin{abstract}
The paper examines the effects of Foreign Direct Investment (FDI) on the economic growth of Lao People's Democratic Republic (Lao PDR) between 1993 and 2015. The investigation is based on the influence of growth and economic absorptive capability determinants such as human capital, trade openness, and institutional quality. The methodological analysis uses a multivariate framework accounting capital stock, labor stock, FDI, human capital, trade openness, and institutional quality in regression of the Vector Autoregressive model. Augmented Dickey-Fuller unit root test, Johansen Cointegration test, and Granger Causality test were applied as parts of the econometric time-series analysis approach. The empirical results demonstrate the positive effects of FDI and trade openness, and the negative effects of human capital and institutional quality on the economic growth of the Lao PDR over the 1993 to 2015 period. The findings confirm that trade openness complemented by a sufficient level of infrastructure, education, quality institutions, and transparency significantly influence economic growth and attract more FDI. Research results lend credence to the need for the Lao PDR's government to focus on improving its economic absorptive capability and economic competitiveness regionally and globally by improving wealth and resource management strategies, as failure to take this course of action could lead to the Dutch Disease effects.
\end{abstract}

Keywords: Foreign Direct Investment, Economic Growth, Absorptive Capability, Human Capital, Trade Openness, Institutional Quality, Lao PDR.

JEL Classification Code: DO11, O47, O53.

\section{Introduction}

The 2018 hydroelectric dam collapse in the Lao People's Democratic Republic (Lao PDR) has raised serious concerns regarding the economic development ambitions of its government in becoming the battery of Southeast Asia. As recently reported by the country's Ministry of Energy and Mines (MEMs), Lao PDR is planning to operate hundreds of

1 First Author. Faculty-Economics and Fiscal Management, College of Local Administration, Khon Kaen University, Thailand.

Email: nantha@kku.ac.th

2 Corresponding Author. Post-Doctoral Researcher, Saint Mary's University of Minnesota [Postal Address: 9200 Queensland Ln N., Maple Grove, MN 55311, USA]. Email: exkang14@smumn.edu

() Copyright: Korean Distribution Science Association (KODISA)

This is an Open Access article distributed under the terms of the Creative Commons Attribution NonCommercial License (https://creativecommons.org/licenses/by-nc/4.0/) which permits unrestricted noncommercial use, distribution, and reproduction in any medium, provided the original work is properly cited. hydroelectric power dams by 2020 (UNDP \& MPI, 2016). Not only will this number of projects pose environment and safely concerns, in the long-run, the country needs to sustain a sufficient level of capability in resource management knowledge and expertise across all sectors in order to avoid Dutch Disease effects (a causal link between the boom of development in natural resource sectors and the decline of development in other sectors, Corden \& Neary, 1982). This concern has been identified in the studies of the Lao PDR's economy for some years (e.g., Menon \& Warr, 2013; Insisiengmay, Nolintha, \& Park, 2015). Taguchi and Khinsamone (2018) found that over the period 1970 to 2015, the economy of the Lao PDR suffered from Dutch Disease effects due to a lack of funding reallocation from natural resource revenues, impacting its overall business environment.

Since the beginning of its modern economic development and despite being categorized as one of the world's least 
developed countries (LDCs), from 1986-2014, Lao PDR was one of the fastest growing economies in Southeast Asia with above $7 \%$ average growth rate (United Nations, 2015). In 2015, the country achieved significant progress by reaching all time high gross national income (GNI) per capita of 1,740 US dollars and was subsequently ranked as a low-middle income economy. Much of this achievement was attributed to an economic boom driven primarily by foreign direct investment (FDI) in natural resource extraction and hydropower (UNDP \& MPI, 2016).

According to the World Bank (2016a), over the past decade, the economic growth of the Lao PDR, to a large degree, was driven by the FDI inflows in mining and hydropower sectors, which are highly capital intensive but did not create a large number of jobs when compared to FDI inflows in the manufacturing sector. Concurrently, there was no significant innovations nor technological development have occurred in other industries that would increase economic productivity and sustainable growth performance in the long run. This raised a great concern on its overall economic absorptive capability if the country is to transition to a more sustainable industrial and services focuseddevelopment.

Over the past three decades, a number of studies have focused on the effects of FDI inflows on the economic growth of the Lao PDR. However, none have been dedicated specifically to exploring the level of the existing absorptive capability of the country. To further the exploration of the relationship between FDI and economic growth regarding the influence of economic absorptive capability for the case of the Lao PDR, this study incorporated both economic and institutional indicators, such as human capital, trade openness, and institutional quality, as proxies for growth factors and the absorptive capability.

\section{Literature Review}

\subsection{Foreign Direct Investment (FDI) Overview}

Foreign Direct Investment (FDI) is a category of crossborder investments in which, through ownership, joint venture, or green field development, residents of one country gain access to managerial power and a significant degree of influence on the management of businesses in another country (World Bank, 2016a). A number of existing studies have corroborated that FDI contributes substantial benefits to the world economy and, in particular, the development of developing economies across the world. In addition, FDI was seen as the key factor in solving the economic crises in developing countries (Mencinger, 2003), for instance, the Latin American debt crisis of the 1980s, the 1994-1995 Mexican crisis, and the 1997-1998 Asian Financial Crisis (Loungani \& Razin, 2001).

Research findings have suggested that FDI inflows can directly and indirectly benefit the economic development of the host country. The direct effect of FDI can be seen through the accumulation of capital inflows, which contributes to increases in employment and productivity. The indirect effect of FDI associates with a broader scope of economic development issues, including labor turnover and linkages formed between foreign firms and domestic firms, technology and knowledge transfers, and access to markets and resources (Anwar \& Nguyen, 2010; Denisia, 2010). In other words, the direct effect of FDI arises through increasing the domestic GDP resulting from the increase of capital and employment; the indirect effect is realized through the effects of spillovers such as knowledge and technology transfer, which subsequently increases the competitive advantages of the domestic firms.

Since the 1960s, the phenomenon of transnational corporations and FDI has featured prominently in the development economics and corresponding research focused on both the positive benefits and negative impacts of FDI (Denisia, 2010). More recently, FDI studies have expanded to include the exploration of the characteristics of different developing economies in terms of generating benefits from FDI inflows. This includes research exploring how an economy's absorptive capability plays a role in catalyzing the benefits from the FDI inflows and attracting future foreign investments.

Theoretically, FDI is considered a major source of inward capital accumulation for transition and developing economies, which directly stimulates domestic growth by increasing employment. Furthermore, FDI indirectly benefits the host country's economy by linking access to the international market, transferring resources such as new and advanced technologies, and increasing competitive advantages. Such direct and indirect benefits of FDI have been clearly articulated, among others, in studies of a host country's absorptive capabilities in the case of Vietnam and Mozambique by Anwar and Nguyen (2010) and Gonzalez, Miura, Moraes, Feijo, and Carvalho (2014).

Nguyen, Duysters, Patterson, and Sander (2009) described FDI as a flow of capital with subsequent spillovers such as technology and know-how from one country to another country. In this context, FDI directly affects economic growth by exerting more capital accumulation into the host economies, which results in an increase in productivity and output from the production model. Indirectly, technology and know-how transfer or improvement are considered contributors to the exogenous effect (unmolded effect) according to the Solow-Swan (1956) growth model, 
but could also cause endogenous effects according to Romer's $(1986,1994)$ model. In the traditional Solow growth model, FDI helps increase host countries' investment and exceeds their domestic saving capacity. As a result, there is a short-term increase in capital accumulation and potential beneficial impact of FDI on output growth (Das \& Das, 2012). In the long term, given the diminishing marginal returns to physical capital, the host economy could either converge to a steady state of growth rate, leaving no permanent impact on the growth of the economy (De Mello, 1997) or, as suggested by endogenous growth models, enjoy the growth rate provided it generates increasing returns in production via externalities and production spillovers (Das \& Das, 2012).

\subsection{Economic Absorptive Capabilities}

In development economics, the absorptive capability of an economy refers to the ability to access, learn about, and absorb new knowledge and technologies into economic productivity in a meaningful manner (Kalotay, 2000; Rogers, 2004). Over the past three decades, different researchers have used different proxies of absorptive capability in the study of economic growth and the effects of FDI on growth. For example, Rogers (2004) employed data for students studying abroad, telecommunications, publications, patent, and trade data in examining how absorptive capability influences economic growth; Silajdzic and Mehic (2016) used research and development (R\&D) indicators as proxies for absorptive capability in examining how FDI affects growth in GDP.

Spillover theory describes the concept that economic specificities including country and industry characteristics have a strong relationship with spillover occurrence. This suggests a high degree of heterogeneity exists across industries due to the differences in learning capabilities and technology absorbing capacity (Bruhn \& Calegario, 2014). Given that "absorptive capability consists of three major elements including accessibility to overseas technology, learning ability, and the incentives or barriers to implementing new technologies" (p.579), Rogers (2004) stated that business, educational and social links, the level of trade in goods and services, and FDI are determining factors of accessibility to overseas technology of the host country. Additionally, while the ability to learn about and understand new technology depends on factors such as human capital, incentives to implement new technologies depend on economic, social, and political factors, such as property rights, the rule of law, and the degree of corruption.

Kalotay (2000) stated that economic absorptive capacity denotes the maximum amount of FDI and spillovers that a host economy can assimilate and integrate into its productivity in a meaningful manner. Similarly, Khordagui and Saleh (2013) described absorptive capacity as the ability of an economy to absorb the benefits spilled over by FDI. In this context, Zahra and George (2002) explained the absorptive capacity in two dimensions, viz. potential capacity and realized capacity. The former means acquisition of knowledge and assimilation of capacities. The latter means transformation of existing knowledge and exploitation of new knowledge. Nguyen et al. (2009) identified some crucial determining factors of economic absorptive capacity factors, which include human capital, financial development, trade openness, quality of institutions, and infrastructure.

In more detail, Borensztein, De Gregorio, and Lee (1998) found that FDI encourages growth only in countries where the labor force has attained a certain level of education. Bengoa and Sanchez-Robles (2003) showed that FDI is positively correlated with economic growth and that the enjoyment of the benefits from long-term FDI inflows requires the FDI host countries to have human capital, economic stability, and liberalized markets. Nunnemkamp (2004) noted the necessity of a country to sustain a minimum level of economic development before exploiting the benefits from FDI. Alfaro, Chanda, Kalemli-Ozcan, and Sayek (2004) drew attention to financial markets by stating that FDI promotes economic growth in economies with sufficiently developed financial markets. Similarly, Sjoholm (1999), Durham (2004), Harris and Li (2009), and Kim (2016), among others, argued that the absorptive capacity of a host country is a key factor in optimizing the full benefits of FDI-generated spillovers. In addition, the spillover effects of FDI inflows could not occur solely from the presence of multinational corporations (MNCs), but also with the presence of sufficient levels of absorptive capability in the host economies, such as the presence of support structures and institutions, interactions and trade orientation, firm size, ownership structure, performance, firm strategy, and industry structure (Gachino, 2010).

\subsection{Lao PDR Economic Growth Determinants}

Over the last decade, the Lao PDR has been one of the fastest growing economies in ASEAN and the 13th fastest growing economy globally, with an average growth rate of over $8 \%$ per year (World Bank, 2016b). This substantiates the notion that Lao PDR's economy is gradually shifting away from agriculture reliance. Yet, agriculture remains one of the main contributors to economic growth of the country, with over 2 million adults, or approximately $64 \%$ of the country's workforce, engaged in agriculture (World Bank, $2016 \mathrm{~b})$. The productivity in agriculture and performance in manufacturing remain low and limited due to a lack of adequate infrastructure, technological progress, and high 
skilled workers. According to a recent country report by the World Bank (2016b), the average agricultural value added per hectare (in 2005 US dollar prices) was US $\$ 578$, compared to US $\$ 994$ in Thailand and US $\$ 1,380$ in Vietnam.

A gradual increase in trade openness subsequent to the introduction of the New Economic Mechanism (NEM, 1986) and the promulgation of investment promotion laws (1988, 1994, 2004) have made the Lao PDR more attractive to foreign investments. FDI inflows, specifically in the natural resources and hydropower sectors, have increased substantially over the period 1988 to 2015 , from merely US \$2 million in 1988 to US $\$ 102$ billion in 2015 (ADB, 2017). Although, evidently, FDI in the natural resource sector over this period did not create sufficient job opportunities in the Lao PDR's economy, highly capital intensive FDI has helped sustain the high growth rate in GDP over the years. As a result, the engine of growth in GDP over this period was largely the natural resource sector. As of 2016, in electricity industry, there were 369 hydropower production project contracts under construction in Lao PDR, excluding 38 projects that were under operation across the country with total installation capacity of $6,258.95$ megawatts. In mining industry, in 2016, there were 74 small and medium-sized exploration contracts, 25 of which were at the stage of preparation for exploration and construction of a processing factory, and 49 of which have been extracting, processing and exporting (UNDP \& MPI, 2016).

While FDI inflows into power and mining construction projects remains robust, emerging real estate development projects also seem to attract a large portion of FDI inflows, especially in the manufacturing and industry sectors, including garments, electronic supplies, and automobile and machinery assembling. FDI inflows in the manufacturing and industry sectors are observed through the development of Special Economic Zones (SEZs), infrastructure, and transportation systems. Although the SEZs have long been promoted, development only started to receive major foreign investment attention in 2005. As of 2016, 13 SEZs have been established throughout the country, with investment contract values of over US $\$ 5$ billion (World Bank, 2016b). Among 249 registered business units in the SEZs, 49.37\% invested in services sectors, $34.6 \%$ invested in commercial sectors, and $16.03 \%$ invested in industry sectors (UNDP \& MPI, 2016).

With the evidence of the continuation of significant effects from the implementation of the NEM (1986) and the catchup effects from FDI spillovers (technology and knowledge transfers) on the economic growth of Lao PDR, it follows that trade openness and the increase of FDI inflows are the key determinants of growth. In addition, the continuation of growth of natural resources, such as mineral mining, hydropower projects, agriculture, and forestry, over the last three decades confirms that they remain key contributors to growth. Therefore, in identifying the growth and FDI absorptive capability determinants in this research, we took into account the factors that play significant roles in attracting investments and increasing productivity in the aforementioned sectors. Such determinants include, among others, human capital, trade openness, institutional quality, development of financial institutions, and infrastructure

\subsection{FDI in the Lao PDR}

As of 2015, the sectoral distribution of FDI inflows into the Lao PDR remained concentrated in the natural resources sector. However, there was an increasing trend in sectors such as real estate development, energy, and agriculture. According to the MPI (2016), the largest recipient of FDI in 2015 was the hydropower sector, which accounted for $45 \%$, followed by the agriculture and mining sectors which accounted for $37 \%$ and $14 \%$, respectively, while manufacturing and handicrafts, services, garments, and hotel and restaurant sectors made up the remaining $5 \%$ of FDI inflows in the same year. During this same period, while sectors involved in natural resources received more than half of the total FDI inflows, they employed only $0.4 \%$ of the total labor force; in contrast, the manufacturing sector contributed as much as $7.3 \%$ to the labor force (ADB, 2017). In 2016, the majority of FDI inflows into the Lao PDR were distributed among infrastructure, energy, hydropower, and manufacturing, and investors from China and ASEAN remain dominant investors in the country.

In a study of the effects of FDI on economic growth and inequality in the Lao PDR, Nolintha (2015) highlighted that, while FDI is an important source of knowledge and technology transfers through local subsidiaries in the Lao PDR, export and import intensities, together with the quality of host institutions, are found to be equally important for firms' technological improvement.

In a study examining the characteristics of FDI in the Lao PDR and its effects on growth and enterprise performance, Saingaleuth (2013) corroborated that minerals \& fuel exports, manufacturing exports, labor productivity, degree of openness, and the impact of the Asian financial crisis are the major determinants of FDI inflows into the Lao PDR. While there is no evidence of market-seeking FDI in the Lao PDR, Saingaleuth (2013) suggested that the country needs to develop the abilities of its local firms and skilled labor to be able to absorb the spillover effects from FDI inflows, particularly in the manufacturing sector. To accomplish this, a set of policies aimed at strengthening investment in knowledge and human capital is vital and ought to be prioritized. 
In a study of the determinants of FDI in the Lao PDR, examining a case study of an Australian mining company, Sisombat (2007) highlighted three motivations for foreign firms to invest in the Lao PDR. First, foreign firms take advantage of its unexploited natural resources. Second, the Lao PDR's market has high growth potential as it becomes more regionally integrated. Third, the Lao PDR's investment promotion laws offer attractive policy incentives as does its highly stable political environment. However, the study concluded that the Lao PDR still possesses limitations that are not favorable for foreign investment, such as the underdeveloped telecommunications infrastructure, inadequate road networks in rural areas, bureaucratic red tape, the lack of a modern technology infrastructure, and a lack of skilled personnel to manage the emerging market economy (Sisombat, 2007).

Similarly, Souvannaphady (2013) highlighted, in a study of trade and FDI into the Lao PDR, that compared to Vietnam and Thailand, the amount of FDI into the Lao PDR is relatively low because of three major factors. The first factor includes not meeting requirements for multinational operations, which involve sufficient local skilled labor, ranging from managers to technicians and engineers to accountants. The second factor involves inadequate public and private infrastructure, which include utilities, telecommunications, logistics, transportation, services, and legal systems. The third factor lies in its small market size, which is incapable of absorbing the large volume of affiliate production by multinationals if they were to exist in the Lao PDR.

In summary, the extant literature of FDI studies in the Lao PDR indicates that while FDI inflows have been considered a substantial source of capital accumulation and a channel of technology and knowledge transfer into the country, the ability to effectively capitalize new knowledge and technologies is dependent on the country's economic absorptive capability. Due to limitations on this research, both in time constraint and data availability, we were not able to take into account every key determinant of economic absorptive capability. However, we assessed that the study of human capital, trade openness, and institutional quality would provide significant indication of how economic absorptive capability plays a role in economic growth and in attracting FDI inflows into the Lao PDR.

\section{Methodology}

\subsection{Research Model}

The research model employed the production function as the starting point. The growth accounting approach, suggested by Solow (1956), was used in developing the growth models of the Lao PDR by incorporating the identified growth and FDI determinants, such as FDI, human capital, trade openness, and institutional quality. The data analysis adopted the Pearson correlation test to predetermine the correlations between GDP and FDI and the absorptive capability determinants. The econometric time series analysis of Vector Autoregressive model (VAR), which includes the unit root test, cointegration test, and Granger Causality test, was applied to capture the equilibrium relationship between variables in the models that would help describe their causality links in the short-run and long-run effects.

We derived the growth model equations in the followings:

$$
Y=A * f(K, L, F D I)
$$

Rewriting equation (3.1.3a) in a linear form or taking natural logarithm on both sides gives:

$$
\ln (Y)=\ln (A)+\beta 1 \ln (K)+\beta 2 \ln (L)+\beta 3 \ln (F D I)
$$

Taking a total derivative gives:

$$
\frac{\mathrm{d} Y}{Y}=\frac{d A}{A}+\beta_{1} \frac{\mathrm{d} K}{K}+\beta_{2} \frac{\mathrm{d} L}{L}+\beta_{3} \frac{d F D I}{F D I}
$$

Assuming that $\mathrm{dA}=\Delta \mathrm{A}$ and $\mathrm{gA}=\mathrm{dA} / \mathrm{A} ; d \mathrm{Y}=\Delta \mathrm{Y}$ and $g G D P=d Y / Y ; d K=\Delta K$ and $g K=d K / K ;$ and $d F D I=\Delta F D I$ and $g F D I=d F D I / F D I$.

$$
g G D P=g A+\beta_{1} g K+\beta_{2} g L+\beta_{3} g F D I
$$

To account for significant absorptive capability variables identified in previous studies, a set of independent variables are accounted into the equation (1) as follows:

$$
\begin{aligned}
Y= & A{ }^{*} f(K, L, F D I, \text { Human Capital, } \\
& \text { Trade Openness, Institutional Quality) }
\end{aligned}
$$

Rewriting equation (5) in a linear form or taking logarithms on both sides gives:

$$
\begin{aligned}
\ln (Y)= & \ln (A)+\beta 1 \ln (K)+\beta 2 \ln (L)+\beta 3 \ln (F D I) \\
& +\beta 4 \ln (\text { HumanCapital) } \\
& +\beta 5 \ln (\text { TradeOpenness) } \\
& +\beta 6 \ln (\text { InstitutionalQuality) }
\end{aligned}
$$

Taking a total derivative gives:

$$
\begin{aligned}
& \frac{\mathrm{d} Y}{Y}=\frac{d A}{A}+\beta_{1} \frac{\mathrm{d} K}{K}+\beta_{2} \frac{\mathrm{d} L}{L}+\beta_{3} \frac{d F D I}{F D I} \\
& +\beta_{4} \frac{d(\text { HumanCapital })}{\text { HumanCapital }}+\beta_{5} \frac{d(\text { TradeOpenness })}{\text { TradeOpenness }} \\
& +\beta_{6} \frac{d(\text { Institutional Qaulity })}{\text { InstitutionalQuality }}
\end{aligned}
$$


Rewriting the above equation in the multivariate growth function form, gives:

$$
\begin{aligned}
g G D P= & \beta_{0}+\beta_{1} g K+\beta_{2} g L+\beta_{3} g F D I+\beta_{4} g H U M C \\
& +\beta_{5} g T R A D E+\beta_{6} g I N S T Q+\varepsilon
\end{aligned}
$$

Using the same derivative approach, we constructed FDI model of human capital, trade openness, and institutional quality as follows:

$$
\begin{gathered}
F D I=F(\text { Human Capital, Trade Openness }, \\
\text { Institutional Quality) }
\end{gathered}
$$

Rewriting the above equation in the multivariate growth function form gives:

$$
\begin{aligned}
g F D I= & \beta_{11}+\beta_{7} g H U M C+\beta_{8} g T R A D E \\
& +\beta_{9} g I N S T Q+\varepsilon
\end{aligned}
$$

\subsection{Measurement of Capital Stock}

Over the years, various economic researchers have used different approaches in estimating the capital stock. However, the Steady State Approach suggested by Harberger (1978) and its expanded version by Nehru and Dhareswar (1993) and the Disequilibrium Approach suggested by Griliches (1980) and its expanded version by Fuente and Domenech (2000) are among the most widely deployed approaches. Both of these approaches were derived from the Perpetual Inventory Method. As mentioned earlier in this study, we adopted this method to estimate the capital stock of the Lao PDR. The essence of the Perpetual Inventory Method is to interpret an economy's capital stock in terms of an inventory, assuming that the stock of inventory increases with capital formation or investment (Berlemann \& Wesselhoft, 2014). This means that once an investment has entered the economy's inventory, it will remain there forever. However, because capital stock wears out over time (buildings need repairs, machines deteriorate, and vehicles require new parts), we needed to account for the depreciation value in estimating the capital stock over the long term.

Therefore, a capital, $\mathrm{K}_{\mathrm{t}}$, at the end of the year, $\mathrm{t}$, can be written as a function of the capital stock, $\mathrm{K}_{\mathrm{t}-1}$, at the end of the prior year, $\mathrm{t}-1$, gross investment of the current year, $\mathrm{k}_{\mathrm{t}}$, and consumption (depreciation) of fixed capital occurred in the previous year, Dt-1 as follows:

$$
K_{t}=K_{t-1}+I_{t}-D_{t-1}
$$

Assuming that the initial capital stock depreciates at a rate of $\delta$, we can write

$\mathrm{D}_{\mathrm{t}-1}=\delta * \mathrm{~K}_{\mathrm{t}-1}$ and substitute this in the equation

This gives:

$$
K_{t}=(1-\delta) K_{t-1}+I_{t-1}
$$

\begin{tabular}{|c|c|c|}
\hline & Model & Purpose \\
\hline \multicolumn{3}{|c|}{ GDP Econometric Time Series Models } \\
\hline Model 1 & $g G D P=F(g K, g L)$ & To confirm the robustness of the fundamental model of growth \\
\hline Model 2 & gGDP $=\mathrm{F}(\mathrm{gK}, \mathrm{gL}, \mathrm{gFDI})$ & To examine the influential effects of $\mathrm{K}, \mathrm{L}$, and FDI on GDP. \\
\hline Model 3 & $\mathrm{gGDP}=\mathrm{F}(\mathrm{gK}, \mathrm{gL}, \mathrm{gFDI}, \mathrm{gHUMC})$ & $\begin{array}{l}\text { To examine the influential effects of } \mathrm{K}, \mathrm{L} \text {, and FDI, and HUMC on } \\
\text { GDP. }\end{array}$ \\
\hline Model 4 & gGDP = F (gK, gL, gFDI, gHUMC, gTRADE) & $\begin{array}{l}\text { To examine the influential effects of } \mathrm{K}, \mathrm{L} \text {, and FDI, HUMC, and } \\
\text { TRADE on GDP. }\end{array}$ \\
\hline Model 5 & gGDP = F (gK, gL, gFDI, gHUMC, gTRADE, gINSTQ) & $\begin{array}{l}\text { To examine the influential effects of } \mathrm{K}, \mathrm{L} \text {, and FDI, HUMC, } \\
\text { TRADE, and INSTQ on GDP. }\end{array}$ \\
\hline \multicolumn{3}{|c|}{ FDI Econometric Time Series Models } \\
\hline Model 6 & $\mathrm{gFDI}=\mathrm{F}(\mathrm{gHUMC})$ & To examine the influential effect of HUMC on FDI. \\
\hline Model 7 & $\mathrm{gFDI}=\mathrm{F}(\mathrm{gHUMC}, \mathrm{gTRADE})$ & To examine the influential effect of HUMC and TRADE on FDI. \\
\hline Model 8 & gFDI = F (gHUMC, gTRADE, gINSTQ) & $\begin{array}{l}\text { To examine the influential effect of HUMC, TRADE, and INSTQ } \\
\text { on FDI. }\end{array}$ \\
\hline
\end{tabular}

To account for the capital stock of the initial year (base year), we applied the assumption of the disequilibrium approach, which is written as follows:

$$
K_{t}=\frac{I_{t}}{g_{I}+\delta}
$$

Table 1: GDP and FDI Models Investigated in this Research 
Where $\boldsymbol{I}_{\boldsymbol{t}}$ is the investment of the base year, $\mathrm{t}, \mathrm{gl}$ is the average growth rate of investment for a period of ten years prior to the base year, and $\delta$ is the depreciation rate of capital stock in the specified current year. The annual capital stock appreciation rate of the Lao PDR estimated by Insisiengmai (2006), using Kuznets' method (1955), was at $6.1 \%$ per year. The capital stock depreciation rate for all countries was also found on the Penn World Table (Version 9) developed by Feenstra, Inklaar, and Timmer (2016). In this study, we used the latest reported capital stock depreciation rates in 2014 .

\subsection{Data}

The main sources of the data include: The World Bank's World Development Indicators, World Bank's Worldwide Governance Indicators, Penn World Table (Version 9), and the Barro-Lee Educational Attainment database. Additional data sources, such as the Bureau of Statistics, the International Monetary Fund (IMF), the Ministry of Planning and Investment (MPI) of Lao PDR, and United Nations Conference on Trade and Development (UNCTAD) were used as confirmatory references where needed. The data for GDP, FDI, Capital Stock, Labor Stock, Trade Openness, and Institutional Quality were collected from the World Bank under the Worldwide Development Indicators and Worldwide Governance Indicator categories. Human Capital data were collected from Penn World Table (Version 9) and Barro-Lee database (2016).

GDP data was collected from the World Bank's World Development Indicators (accessed April, 2017). To exclude the effects of the inflation rate, we used the GDP values reported in 2010 US dollar prices using the corresponding annual consumer price index (CPI) reported by the World Bank. The World Bank's World Development Indicators report recorded the FDI data in instant US dollar prices. In this study, we converted the FDI data into the real 2010 US dollar values using the corresponding annual consumer price index (CPI) reported by the World Bank. Capital stock or capital accumulation were calculated using the Perpetual Inventory Method, which accounts for the depreciation of the accumulated capital over time.
Labor stock is reported in terms of the available labor force. Human capital data is collected from the Penn World Table (Version 9) constructed by the University of CaliforniaDavis and the University of Groningen, which uses average year of schooling and return to education as proxies for human capital index.

Trade Openness was calculated as the ratio of trade (sum of import and export of goods and services) over GDP. Institutional Quality was calculated using the average of six Worldwide Governance Indicators (WGI) scores retrieved from the World Bank database (accessed April, 2017). These indicators include political stability, government effectiveness, regulatory quality, rule of law, control of corruption, and voice and accountability.

\section{Results}

\subsection{Pearson Correlation Test}

Pearson correlation test results showed a very weak positive correlation between gGDP and gK, a strong positive-correlation between gGDP and $\mathrm{gL}$, a very weak negative-correlation between gGDP and gFDI, a moderate positive-correlation between gGDP and gHUMC, a very week negative-correlation between gGDP and gTRADE, a moderate positive-correlation between gGDP and gINSTQ, a weak negative-correlation between gFDI and gHUMC, a very weak positive-correlation between gFDI and gTRADE, and a weak positive-correlation between gFDI and gINSTQ.

\subsection{Unit Root Test}

The Augmented Dickey-Fuller (ADF) test was used as a main unit root test method; Phillips-Peron (PP) and Kwiatkowski-Phillips-Schmidt-Shin (KPSS) tests were used to confirm the results. All unit root tests were estimated based on the growth rate unit of each variable and performed under the trend specification with auto-generated lag length based on Schwarz's Information Criteria (SIC).

Table 2: Pearson Correlation Test Result

\begin{tabular}{|c|c|c|c|c|c|c|c|}
\hline $\begin{array}{c}\text { Correlation T-Statistic } \\
\text { Probability }\end{array}$ & & & & & & \\
\hline & gGDP & gK & gL & gFDI & gHUMC & gTRADE & gINSTQ \\
\hline gGDP & 1 & 0.030072 & 0.61007 & -0.01008 & 0.50954 & -0.04084 & 0.44417 \\
\hline & & 0.099783 & 2.553646 & -0.03342 & 1.964043 & -0.13557 & -1.64424 \\
\hline gFDI & & 0.9223 & 0.0268 & 0.9739 & 0.0753 & 0.8946 & 0.1284 \\
\hline & & & & 1 & -0.19832 & 0.091863 & 0.228968 \\
\hline & & & & & -0.67109 & 0.305969 & -0.64786 \\
\hline & & & & & 0.516 & 0.7653 & 0.5304 \\
\hline
\end{tabular}


The ADF unit root test, with the confirmation of PP and KPSS unit root tests, indicated that variables consisted in each model are not stationary at level but at first differences. Because the growth rate variables are integrated of order one, I(1), for variables that were not stationary at level, taking the first differences was enough to reach stationarity.

Table 3: Augmented Dickey-Fuller (ADF) Unit Root Test Result

\begin{tabular}{|lccll|}
\hline \multicolumn{1}{|c}{ Variables } & $\begin{array}{c}5 \% \text { Critical } \\
\text { Values }\end{array}$ & $\begin{array}{c}\text { ADF Stat at } \\
\text { Level }\end{array}$ & \multicolumn{1}{c|}{ Null Hypothesis } & Result \\
\hline gGDP & -3.020686 & -1.481773 & gGDP has a unit root & Accepted \\
gFDI & -3.012363 & -4.572224 & gFDI has a unit root & Rejected \\
gK & -3.020686 & -3.070197 & gK has a unit root & Rejected \\
gL & -3.052169 & -0.899177 & gL has a unit root & Accepted \\
gHUMC & -3.632896 & -2.329351 & gHUMC has a unit root & Accepted \\
gTRADE & -3.020686 & -5.461037 & gTRADE has a unit root & Rejected \\
gINSTQ & -3.144920 & -8.105015 & gINSTQ has a unit root & Rejected \\
\hline
\end{tabular}

\subsection{Cointegration Test}

The cointegration trace test was undertaken using the methodology developed by Johansen (1991, 1995). The purpose of the test was to investigate whether a significant long-run equilibrium relationship exists among variables in each model developed for each country. The test results indicated that all variables in each model are cointegrated of the same order, I(1), with at least one co-integrating equation. This concluded that there exists long-run relationship between variables.

Table 4: Unrestricted Johansen Cointegration Rank Test (Trace)

\begin{tabular}{|c|c|c|c|c|}
\hline Hypothesized & & Trace & $\mathbf{0 . 0 5}$ & \\
\hline No. of CE(s) & Eigenvalue & Statistic & $\begin{array}{c}\text { Critical } \\
\text { Value }\end{array}$ & Prob.** $^{* 1}$ \\
\hline None * $^{*}$ & 0.978343 & 203.0404 & 95.75366 & 0.0000 \\
\hline At most 1 * & 0.952128 & 126.3919 & 69.81889 & 0.0000 \\
\hline At most 2 * & 0.720030 & 65.60753 & 47.85613 & 0.0005 \\
\hline At most 3 * & 0.602305 & 40.14605 & 29.79707 & 0.0023 \\
\hline At most 4 * & 0.546852 & 21.70465 & 15.49471 & 0.0051 \\
\hline At most 5 * & 0.254498 & 5.873936 & 3.841466 & 0.0154 \\
\hline Trace test indicates 6 cointegrating eqn(s) at the 0.05 level \\
\hline * denotes rejection of the hypothesis at the 0.05 level \\
\hline **MacKinnon-Haug-Michelis (1999) p-values \\
\hline
\end{tabular}

\subsection{Vector Autoregression Model (VAR) Estimation}

The results of GDP models (Model 1 to Model 5) showed that: the relationship between $\mathrm{gK}$ and gGDP is positive in Models 1, 2, 3, and 5, and negative in Model 4. The relationship between $\mathrm{gL}$ and gGDP is positive in Model 1, 2, 3 , and 4 , and negative in Model 5. The relationship between
gFDI and gGDP is positive in Model 2, 3, and 5, and negative in Model 4. The relationship between gHUMC and gGDP is positive in Model 3, and negative in Models 4 and 5. The relationship between gTRADE and gGDP is positive in Models 4 and 5 . The relationship between gINSTQ and gGDP is positive in model 5.

The results of FDI models (Models 6 to Model 8) showed that the relationship between $\mathrm{gHUMC}$ and $\mathrm{gFDI}$ is positive in Models 6 and 7, and negative in Model 8. The relationship between gTRADE and gFDI is positive in Models 7 and 8 . The relationship between gINSTQ and gFDI is negative in Model 8. As a result, we concluded that, for GDP models, there are positive effects of gFDI, gTRADE, and gINSTQ and negative effect of gHUMC on the gGDP of Lao PDR. For FDI models, gHUMC and gTRADE have positive effects on gGDP, while gINSTQ has a negative effect on gGDP.

Table 5: Summary of Unrestricted VAR Results of Lao PDR

\begin{tabular}{|c|c|c|c|c|c|c|c|c|c|c|}
\hline \multirow[t]{2}{*}{ Lao PDR } & \multicolumn{6}{|c|}{ GDP Models } & \multicolumn{4}{|c|}{ FDI Models } \\
\hline & M1 & M2 & M3 & M4 & M5 & Result & M6 & M7 & M8 & Result \\
\hline gK & + & + & + & - & + & + & & & & \\
\hline $\mathrm{gL}$ & + & + & + & ++ & - & + & & & & \\
\hline gFDI & & + & + & - & + & + & & & & \\
\hline gHUMC & & & + & -- & - & - & + & + & - & + \\
\hline gTRADE & & & & ++ & + & + & & + & + & + \\
\hline gINSTQ & & & & & + & + & & & - & - \\
\hline $\begin{array}{l}5 \% \text { short- } \\
\text { run } \\
\text { relation- } \\
\text { ship }\end{array}$ & gK & gK & None & None & None & None & None & None & None & None \\
\hline $\begin{array}{l}5 \% \text { long- } \\
\text { run } \\
\text { relation- } \\
\text { ship }\end{array}$ & None & None & None & None & None & None & $\mathrm{gHUMC}$ & None & None & None \\
\hline $\begin{array}{l}\text { *the regre } \\
(+) \text { Posit } \\
(++) \text { Sigr } \\
\text { (-) Negat } \\
\text { (--) Signi }\end{array}$ & $\begin{array}{l}\text { sion } \\
\text { e rela } \\
\text { icant } \\
\text { e rel }\end{array}$ & $\begin{array}{l}\text { of the } \\
\text { ations } \\
\text { t posit } \\
\text { lations }\end{array}$ & $\begin{array}{l}\text { mode } \\
\text { hip } \\
\text { tive re } \\
\text { ship }\end{array}$ & lis $\mathrm{s}$ & gnifica & ant at 5 & $\begin{array}{l}\% \text { leve } \\
\text { vel }\end{array}$ & & & \\
\hline
\end{tabular}

\subsection{Granger Causality Test}

Using the pairwise test method, the Granger causality test results of GDP model indicated two significant Granger causalities of independent variables on dependent variable, gGDP. These Granger causalities are: (1) gINSTQ Granger causes gGDP of the Lao PDR, (2) gGDP Granger cause gL of the Lao PDR. The Granger causality test results of FDI model indicated one Granger causality moving from independent variables to dependent variable and two Granger causalities moving from dependent variable to independent variables. These include: (1) gHUMC Granger causes gFDI of the Lao PDR. 


\section{Conclusion}

The empirical results demonstrate the positive effects of FDI and trade openness, and the negative effects of human capital and institutional quality on the economic growth of the Lao PDR over the 1993 to 2015 period. The positive effect of FDI on GDP found in this research accords with the findings of the study by Saignaleuth (2013), who found that FDI positively affects the economic growth of the Lao PDR differently across sectors. Nolintha (2015) found that FDI inflows in the natural resource sector positively affect the economic growth of the Lao PDR. The positive relationship between FDI and GDP was also evident in the Pearson correlation test of the collected data for the 1993 to 2015 period, which shows that the two variables are positively correlated.

The positive effect of trade openness on the economic growth of Lao PDR draws a linkage between FDI inflows and trade in the country. The increase in FDI inflows and FDI diversity in the Lao PDR over the 1993 to 2015 period triggered the expansion of regional and international trade relationships of the country and subsequently led to the increase in the export of goods such as timber, electricity, and minerals. Furthermore, the expansion of trade in the Lao PDR also increased the import of new technologies and knowledge through consumption goods, imitation, and investment in domestic production. Souvannaphakdy (2013) found positive effect of FDI-trade linkage on the economic growth of the Lao PDR and stated that, in the Lao PDR, trade and FDI are complements with respect to changes in relative physical capital endowment and are substitutes with respect to transportation costs, relative human capital endowment, and relative labor endowment. Furthermore, the combined effects of trade and FDI, which led to the expansion of the international trade, has increased the production efficiency in the Lao PDR more than $28 \%$ over the period 1995 to 2010 (Souvannaphakdy, 2013).

The negative effect of human capital and institutional quality on the GDP of the Lao PDR also draws a linkage between the two variables. Improving in human capital means improving in level and quality of education, which in the long-run contribute to the improvement of institutional quality through the advancement of knowledge, skills, and ability to adapt to new technologies being transferred through FDI inflows. In theory, improvement in these two variables would increase the economic activity output or GDP in terms of the increase in savings and income per capita. Saignaleuth (2013) found that trade openness positively impacts FDI inflows into the Lao PDR, which is in line with Yamagat (2006) and Cuyvers, Soeng, Plasmans, and Van den Bulcke (2008), who confirmed that a higher level of trade openness creates a more attractive investment environment to FDI inflows. Moreover, trade openness also plays a significant role in channeling the relationship between domestic and foreign firms and in transferring knowledge and technologies. However, the negative effects of human capital and institutional quality on GDP found in this research could have resulted from no level of improvement over the time period explored in this study. Slow or little improvement in these two variables over the period 1993 to 2015 may have generated insignificant effect and unobservable change to the GDP.

The assessment of the impact of human capital, trade openness, and institutional quality on FDI inflows into the Lao PDR shows that there are positive effects of human capital and trade openness on FDI inflows, while institutional quality appears to negatively affect FDI inflows into the country over the period 1993 to 2015 . This means that foreign investors weigh their investment decisions in the Lao PDR more on human capital and trade openness factors than the institutional quality factor. The FDI trend and sectors that received FDI the most in the Lao PDR provide some supporting evidence for these results. Over the period 1993 to 2015, the natural resource sector received the most FDI inflows in Lao PDR with an increasing trend over years. Resource-seeking FDI would care less about institutional quality, but rather pay more attention to the lower cost of labor and the host country's trade liberalization and trade partners.

\section{Recommendations}

Based on the empirical results, this research proposes the following recommendations:

First, to sustainable long-term growth, the government of the Lao PDR and its policy makers need to continue promoting FDI and developing FDI-focused policies to encourage investment in sectors in which the Lao PDR has comparative and competitive advantages. These include agriculture, minerals, small-scale manufacturing, tourism, and the energy sector, such as solar energy and hydropower projects.

Second, improving the quality of FDI is equally important in sustaining long-term growth. Therefore, the government of the Lao PDR needs to continue to implement investment policies that attract better quality and more sustainable FDI and refrain from implementing over-generous FDI promotion schemes which could lead to a substantial opportunity cost at the macroeconomic level, especially in increasingly sensitive hydropower schemes (see Blake \& Barney, 2018; Olson \& Morton, 2018), not least when dams fail.

Third, while trade openness can be considered as the gateway to reach out to and welcome foreign investors, a 
sufficient level of infrastructure, education, quality institutions, and transparency would assure investors of profitable investments. Therefore, aside from continuing to encourage FDI, the government of the Lao PDR needs to focus on improving its economic absorptive capability and economic competitiveness regionally and globally. As a natural resource-rich economy, one way for Lao PDR to effectively improve its absorptive capability is through better wealth and resource management strategies, such as diversification, thereby limiting the risk of the Dutch Disease effects.

\section{References}

ADB. (2017). Country Diagnostic Study: Lao PDR: Accelerating Structural Transformation for Inclusive Growth. Mandaluyong City, Philippines: ADB Publishing. Retrieved from https://www.adb.org/sites/default/f

Alfaro, L., Chanda, A., Kalemli-Ozcan, S., \& Sayek, S. (2004). FDI and economic growth: The role of local financial markets. Journal of International Economics, 64(1), 89-112.

Anwar, S., \& Nguyen, L. P. (2010). Absorptive capacity, foreign direct investment-linked spillovers and economic growth in Vietnam. Asian Business \& Management, 9(4), 553-570.

Barro, R. J. (2010). Intermediate Macro. Boston, MA: SouthWestern Cengage Learning.

Barro, R. J., \& Lee, J. W. (2013). A New Data Set of Educational Attainment in the World 1950-2010. (2016 update). Journal of Development Economics, 104, 184198.

Bengoa, M., \& Sanchez-Robles, B. (2003). Foreign direct investment, economic freedom and growth: New evidence from Latin America. European Journal of Political Economy, 19, 529-545.

Berlemann, M., \& Wesselhöft, J. E. (2014). Estimating aggregate capital stocks using the perpetual inventory method: A survey of previous implementations and new empirical evidence for 103 countries. Review of Economics, 65, 1-34.

Blake, D. J., \& Barney, K. (2018). Structural Injustice, Slow Violence? The Political Ecology of a "Best Practice" Hydropower Dam in Lao PDR. Journal of Contemporary Asia, 48(5), 808-834.

Borensztein, E., De Gregorio, J., \& Lee, J. W. (1998). How does foreign direct investment affect economic growth? Journal of International Economics, 45(1), 115-135.

Brauer, M., Freedman, G., Frostad, J., Donkelaar, A. V., Martin, R. V., Dentener, F., ... \& Balakrishnan, K. (2017).
The Next Generation of the Penn World Table. Seattle, WA: World Bank.

Bruhn, N. C. P., \& Calegario, C. L. L. (2014). Productivity spillovers from foreign direct investment in the Brazilian processing industry. BAR-Brazilian Administration Review, 11(1), 22-46.

Corden, W. M., \& Neary, J. P. (1982). Booming sector and de-industrialisation in a small open economy. The Economic Journal, 92(368), 825-848.

Cuyvers, L., Soeng, R., Plasmans, J., \& Van den Bulcke, D. (2008). Productivity spillovers from Foreign Direct Investment in the Cambodian manufacturing sector: evidence from establishment-level data (Working Papers 2008004). Antwerpen, Belgium: University of Antwerp, Faculty of Business and Economics.

Das, S., \& Das, T. (2012). A time-series analysis of impact of FDI on economic development in India during postreforms era (1991-2010). Retrieved from http://www.ccsenet.org/journal/index.php/ijbm/article/view File/4649/4213

De Mello, L. R. Jr. (1997). Foreign direct investment in developing countries and growth: A selective survey. The Journal of Development Studies, 34(1), 1-34.

Denisia, V. (2010). Foreign direct investment theories: An overview of the main FDI theories. European Journal of Interdisciplinary Studies, 3. Retrieved from https://ideas.repec.org/a/jis/ejistu/y2010i02id357.html

Durham, B. (2004). Absorptive capacity and the effects of FDI and equity foreign portfolio investment on economic growth. European Economic Review, 48, 285-306.

Feenstra, R. C., Inklaar, R., \& Timmer, M. P. (2015). The next generation of the Penn World Table. American Economic Review, 105(10), 3150-82.

Gachino, G. (2010). Technological spillovers from multinational presence: Towards a conceptual framework. Progress in Development Studies, 10(3), 193-210.

Gonzalez, J. M., Miura, I. K., Moraes, R., Feijo, J., \& Carvalho, J. Z. (2014). FDI inflows, transfer of knowledge, and absorptive capacity: The case of Mozambique. African Journal of Business Management, 8(1), 14. https://doi.org/10.5897/AJBM2013.7017

Granger, C. W. (1969). Investigating causal relations by econometric models and cross-spectral methods. Econometrica: Journal of the Econometric Society, 37(3), 424-438.

Griliches, Z. (1980). R\&D and the Productivity Slowdown (National Bureau of Economic Research Paper No. 0434).

Harberger, A. C. (1978). Perspectives on capital and technology in less-developed countries. Paper presented at the (Annual) Conference of the Association of University Teachers of Economics, April 1977. 
Harris, R., \& Li, Q. C. (2009). Exporting, R\&D and absorptive capacity in UK establishments. Oxford Economic Papers, 61, 74-103.

IMF. (2007). World economic outlook: Growth and institutions. Washington, D.C.: International Monetary Fund.

Insisiengmay, S. (2006). Lao Capital Stock Estimation: ICOR, Growth Projection and Determinant of Inflation. NERI Economic Review, 1.

Insisiengmay, S., Nolintha, V., \& Park, I. (2015). Dutch disease in the Lao economy: Diagnosis and treatment. International Area Studies Review, 18(4), 403-423.

Johansen, S. (1991). Estimation and hypothesis testing of cointegration vectors in Gaussian vector autoregressive models. Journal of the Econometric Society, 59(6), 15511580.

Johansen, S. (1992). Cointegration in partial systems and the efficiency of single-equation analysis. Journal of econometrics, 52(3), 389-402.

Kalotay, K. (2000). Is the sky the limit? The absorptive capacity of Central Europe for FDI. Transnational Corporations, 9(3), 137-162.

Khordagui, N. H., \& Saleh, G. (2013). FDI and absorptive capacity in emerging economies. Topics in Middle Eastern and North African Economies, 15. Retrieved from https://ecommons.luc.edu/meea/176/

Kim, M. (2016). Productivity spillovers from FDI and the role of domestic firm's absorptive capacity in South Korean manufacturing industries. Empirical Economics, 48(2), 807-827.

Kyophilavong, P., \& Toyoda, T. (2008). Foreign capital inflows in the natural resources sectors: Impacts on the Lao economy. In Future of Economic Integration in Asia Conference, Bangkok, Thailand.

Loungani, P. \& Razin, A. (2001). How beneficial is foreign direct investment for developing countries? Finance and Development, 38(2), 6-9.

Mehic, E., Silajdzic, S., \& Babic-Hodovic, V. (2013). The impact of FDI on economic growth: Some evidence from Southeast Europe. Emerging Markets Finance \& Trade, 49(s1), 5-20.

Mencinger, J. (2003). Does foreign direct investment always enhance economic growth? Kilkos, 56(4), 491-508.

Menon, J., \& Warr, P. (2013). The Lao economy: Capitalizing on natural resource exports. Asian Economic Policy Review, 8(1), 70-89.

MPI. (2016). Investment Database. Investment Promotion Department, Vientiane Capital, Laos PDR. Retrieved November 12, 2016 from http://www.investLaos.gov.la/ index.php/resources/statistics
Nehru, V., \& Dhareshwar, A. (1993). A new database on physical capital stock: Sources, methodology and results. Revista de Analisis Economica, 8(1), 37-59.

Nguyen, H. T., Duysters, G., Patterson, J. H., \& Sander, H. (2009). Foreign direct investment absorptive capacity theory. Georgia Institute of Technology. Retrieved from https://smartech.gatech.edu/handle/1853/35267

Nolintha, V. (2015). The Effects of FDI on Economic Growth and Inequality in Laos (Doctoral dissertation). Graduate School of Economics and Business Administration, Reitaku University, Kashiwa, Japan.

Nolintha, V., \& Jajri, I. (2016). The garment industry in Laos: technological capabilities, global production chains and competitiveness. Asia Pacific Business Review, 22(1), 110-130.

Nolintha, V., \& Yee, L. (2015). Lao PDR's economic growth: The role of capital accumulation and the natural resource sector. Reitaku Economic Research, 22(1), 49-69.

Olson, K. R., \& Morton, L. W. (2018). Water rights and fights: Lao dams on the Mekong River. Journal of Soil and Water Conservation, 73(2), 35A-41A.

Rogers, M. (2004). Absorptive capability and economic growth: how do countries catch-up? Cambridge Journal of Economics, 28(4), 577-596.

Romer, P. M. (1986). Increasing returns and long-run growth. Journal of Political Economy, 94(5), 1002-1037.

Romer, P. M. (1994). The origins of endogenous growth. Journal of Economic Perspectives, 8(1), 3-22.

Saignaleuth, S. (2013). Characteristics of FDI in Lao PDR and Its Effect on Growth Enterprise Performance (Doctoral dissertation). Graduate School of Economics and Business Administration, Kobe University, Kobe, Japan.

Silajdzic, S., \& Mehic, E. (2016). Absorptive capabilities, FDI, and economic growth in transition economies. Emerging Markets Finance \& Trade, 52(4), 904-922.

Sisombat, S. (2007). Determinants of foreign direct investment in Laos: A case study of an Australian mining company (Doctoral dissertation). Graduate School of Economics and Business Administration, Victoria University, Victoria, Canada.

Sjoholm, F. (1999). Productivity growth in Indonesia: The role of regional characteristics and direct foreign investment. Economic Development and Cultural Change, 47(3), 53-73.

Solow, R. M. (1956). A contribution to the theory of economic growth. Quarterly Journal of Economics, 70(1), 65-94.

Spence, M. (2011). The next convergence: The future of economic growth in a multispeed world. New York, NY: Farrar, Straus and Giroux. 
Suvannaphakdy, S. (2013). An empirical study of trade and foreign direct investment in Laos (Doctoral dissertation). Hiroshima Shudo University, Hiroshima, Japan.

Taguchi, H., \& Khinsamone, S. (2018). Analysis of the 'Dutch Disease' Effect on the Selected Resource-Rich ASEAN Economies. Asia \& the Pacific Policy Studies, 5(2), 249-263.

UNDP \& MPI. (2016). The 8th Five-Year National Socioeconomic Development Plan (2016-2020). Retrieved from http://www.la.undp.org/content/Lao_pdr/en/home/ library/poverty/the-8th-five-year-national-socio-economicdevelopment-plan--2016.html

United Nations. (2015). Country analysis report: Lao People's Democratic Republic (pp.1-39). Retrieved from http://www.la.one.un.org/media-center/publications/173country-analysis-report-1

World Bank. (2016a). What is the difference between Foreign Direct Investment (FDI) net inflows and net outflows?

World Bank. (2016b). Lao Economic Monitor FY15-16. Challenges in promoting more inclusive growth and shared prosperity.

Yamagata, T. (2006). The garment industry in Cambodia: Its role in poverty reduction through export-oriented development. Cambodian Economic Review, 2, 81-136.

Zahra, S. A., \& George, G. (2002). Absorptive capacity: A review, reconceptualization, and extension. Academy of Management Review, 27(2), 185-203. 